\title{
Deindustrialization and innovation under globalization: an analysis of India's catch up in manufacturing
}

Desindustrialização e inovação na globalização: uma análise do catch up indiano na manufatura

\author{
KJJoseph $^{(1)}$ \\ Kiran Kumar Kakarlapudi(1) \\ Akhil Joseph (2) \\ (1) Gulati Institute of Finance and Taxation \\ (2) Wealthmaker Financial Services
}

\section{Abstract}

There is a growing empirical evidence of premature deindustrialization in developing countries wherein the share of manufacturing in GDP and employment declined at a much lower level of per capita income as compared to the trend observed in developed countries. This study examined the manufacturing performance of India, which has been persistent with industrialization as its catch-up strategy. While the study finds no evidence of deindustrialization in the conventional sense, it presents compelling evidence in terms of wage share in value added and wage rate. Therefore, the study argues that a realistic analysis of deindustrialization should consider the quality of employment, wage share and wage rate along with employment share and GDP share. The study attributes deindustrialization in India as an outcome of its strategy to build international competitiveness based on price/ wage cost advantage and the failure to build a vibrant learning, innovation and competence building system.

\section{Keywords}

India, deindustrialization, quality of employment, innovation.

JEL Codes O14, O25, O33, O38.

\section{Resumo}

Existe crescente evidência empirica de desindustrialização prematura nos países em desenvolvimento, onde a participação do emprego industrial no PIB diminuiu em um nivel muito mais baixo de renda per capita em comparação com os países desenvolvidos. Este estudo examinou o desempenho da indústria da Índia, que tem persistido com a industrialização como estratégia de catch-up. Embora o estudo não encontre evidências de desindustrialização no sentido convencional, ele apresenta evidências convincentes em termos da qualidade do emprego gerado e da sua participação no PIB. Portanto, o estudo argumenta que uma análise realista da desindustrialização deve considerar a qualidade do emprego, a participação e a taxa dos salários, juntamente com a parcela do emprego e do PIB. O estudo atribui a desindustrialização na Índia como resultado da estratégia de ganhar competitividade internacional via vantagens de preço I custo de salário e o fracasso em construir um sistema vibrante de aprendizagem, inovação e construção de competências.

\section{Palavras-chave}

Índia, desindustrialização, qualidade no emprego, inovação.

Códigos JEL O14, O25, O33, O38. 


\section{Introduction}

There has been a consensus among the development economists that industrialization is the key engine of growth and prosperity for developing countries, i.e., the analytical foundation for an industry-driven growth derived from the unique characteristics of manufacturing. This includes, but is not limited to, its potential for higher productivity (Lewis, 1956), and higher linkages (Hirschman 1958), capital accumulation (Rowthorn and Coutts 2004), technological change owing to a higher knowledge/science base and finally the Keynesian-type demand multiplier effects, through the higher wages in manufacturing (Tregenna 2009). The three laws of Kaldor (1966), based on the empirical evidence, were inspirational for policy makers in the developing world to pursue this approach. As a result, in 1950, the share of manufacturing in a sample of 29 largest developing countries was only 11 per cent, compared to 31 per cent in 16 advanced economies. By 1980, the average share of manufacturing in these developing countries had increased to 20 per cent (Szirmai, 2012).

Since circa 1980 there has been a major change of heart among the policy makers with respect to their development strategy. There has been a shift in policy pendulum from planning to market and from import substitution to export orientation and globalization. The focus on industrialization and manufacturing remained unchanged with renewed emphasis on FDI, technology transfer and removal of tariff barriers to further stimulate the growth-pulling characteristics of the manufacturing sector especially after the WTO came into being. At the same time, there is no guarantee that returns to manufacturing-based catch-up strategies like linkages and productivity growth under globalization accrue primarily to the country concerned. No wonder empirical evidence suggested that, as the globalization process accelerated, many of the developing countries that managed to achieve manufacturing momentum under import substitution began to experience an accelerated process of deindustrialization. Even the least developed countries of Sub-Saharan Africa are faced with deindustrialization (Tregenna, 2015) ${ }^{1}$.

1 Deindustrialization has also been attributed as one of the underlying factors behind the middle income trap, yet another current concern of policy makers (Intarakumnerd 2019 for Thailand; Yasar 2019 for Turkey; Albuquerque 2019 for Brazil; and Wong and Fung 2019 for Malaysia). 
Empirical evidence also suggests that between 1970 and 2010 the share of global manufacturing employment and output remained more or less constant at $14 \%$ and $17 \%$, respectively, when several developing countries experienced deindustrialization (Felipe and Mehta 2016). Hence, deindustrialization in developing countries has been viewed in terms of their inability to compete under globalization with countries like China (Atolia et al. 2018; Singh, 1977). To the extent that competitiveness is the key to survival in the globalized world, which in turn is governed by innovation, the relevance of an inquiry into the role of innovation in the observed deindustrialization cannot be overemphasized. Here it is important to note that successful catch-up experience across the world involved the formation of innovation systems through creation of institutional architecture conducive for human capital formation, industrial and technological progress, the formation and development of local firms, and investments in scientific infrastructure (Nelson 2003; Lee 2016).

This study makes a point of departure from the earlier studies in two respects. One, it makes the case for analysing the quality of employment along with the conventional analysis of the share of manufacturing employment in understanding the process of deindustrialization. Second, it also contributes to the literature by explicitly highlighting the role of innovation capabilities in deindustrialization by taking a case of one country -India.

The remainder of the article is organized as follows. Section two presents an overview of the literature on deindustrialization based on the conventional indicators such as share of manufacturing employment and output from a catch-up perspective, and highlights the need for considering quality of employment, wage share and wage rate. Section three briefly discusses data sources used in the study. Section four examines the nature of deindustrialization in India's manufacturing wherein it is argued that while there is no conclusive evidence of deindustrialization based on manufacturing employment, there is compelling evidence of premature deindustrialization viewed in terms of the share of manufacturing in GDP. This riddle is resolved by an analysis of the quality of employment, labour share in value added and real wage rate. Section five highlights the role of innovation in understanding the observed trend and argues that deindustrialization in India has been an outcome of the strategy of building international competitiveness under globalization based on wage cost 
advantage instead of strengthening the learning innovation competence building systems. The last section presents the concluding observations.

\section{Deindustrialization: Theory and evidence}

The issue of deindustrialization, subjected to much analysis by the Cambridge view, has been identified with Singh (1977). It is defined as the process involving a decline in the share of manufacturing output in GDP or a decrease in the share of manufacturing employment (see, for example, Palma, 2008; Rowthorn and Coutts, 2004; Rowthorn and Ramaswamy, 1997; Saeger, 1997; Alderson, 1999; and Dasgupta and Singh, 2005; Tregenna, 2009, 2105 among others). As articulated by (Rowthorn and Wells, 1987), it can be either positive or negative. Positive deindustrialization is regarded as 'the normal result of sustained economic growth in a fully employed, and already highly developed economy arising on account of the rapid productivity growth in the manufacturing sector. As a result, despite increasing output, employment in this sector is reduced, either absolutely or as a share of total employment' (Rowthorn and Wells, 1987, p. 5). In case of developed countries, such a phenomenon takes place when the share of manufacturing in GDP reached $30 \%$ and per capita income $\$ 30,000$. By then, the benefits of manufacturing would have diffused through the economy over an extended period of time.

Unlike the positive deindustrialization, scholars analysing industrial development in developing countries, especially in Latin America, have articulated negative deindustrialization which has also been termed as premature deindustrialization (Plama, 2014; Tregenna 2009; 2015), thus named because it takes place in the developing countries at a much lower level of per capita income and at a far lower level of industrialization as compared to developed countries. Rodrik (2016) estimates that countries that have been experiencing deindustrialization since 1990 were able to report a manufacturing employment share of only 18.9 percent with a per capita income level of \$4,273 in 1990 constant prices versus those countries that experienced deindustrialization prior to 1990 and peaked at an employment share of 21.5 percent with a per capita income level of $\$ 11,048$ in 1990 prices. These developing countries are shown to be turning into service economies without having gone through industrialization at levels of 
income that are a fraction of those at which the advanced economies started to deindustrialize (Rodrik 2005). Evidence also suggests that share of manufacturing employment and value added in African countries showed declining trends even before they embarked upon industrialization and with their per capita income not even reaching \$ 1000 (Tregenna 2015; Atolia et al. 2019). To the extent that deindustrialization in these countries is not preceded by any notable industrial development this has been termed as 'pre-industrialization and deindustrialization' (Rodrik, 2016).

On the whole, going by the available empirical evidence it appears that, while historically manufacturing has served as the main engine of economic growth and development, since 1990 for the developing countries in general manufacturing is becoming a more difficult route to growth than before (Dasgupta and Singh 2006; Szirmai and Verspagen, 2015).

Early studies arrived at the conclusion regarding deindustrialization based on the share of manufacturing in employment. It was observed that in most country experiences of 'deindustrialization', falling manufacturing employment has been accounted for primarily by decreases in the labour intensity of manufacturing, rather than by an overall decline in manufacturing GDP or manufacturing share of total GDP. To the extent that even with decline in employment, manufacturing could act as a catch-up sector Tregenna (2009) argued that a proper empirical analysis of deindustrialization needs to take into account trends in manufacturing output as well as employment. Using both share of manufacturing employment and GDP for a sample of 101 countries, Tregenna (2015) observed that there is an almost universal trend towards deindustrialization, across income and regional groups. One interesting finding from her analysis is that many of the developing countries started de-industrialising after 1990s.

The concern for de-industrialisation viewed either in terms of manufacturing employment or value added arises because of the reduction of the manufacturing sector's ability to act as a growth engine through backward and forward linkages, productivity growth and the associated Keynesian type demand multiplier. However, there is reason to believe that the Keynesian multiplier effect is not guaranteed even with an increase in the share of manufacturing output and employment. This could be the case if higher employment and value-added share is not associated with corresponding increase in wage income. In developing countries, there are empirical studies to suggest that in the event of heightened international 
competition, firms resort to wage cutting strategies (Joseph and Kakarlapudi, 2019). There are also studies that make the case for flexible labour markets in developing countries, which in turn could lead to low quality employment. Thus viewed, an analysis of deindustrialization grounded in Keynesian type multiplier effect should also consider quality of employment in addition to value added and employment share.

\subsection{Deindustrialization and globalization}

In the context of globalization and Global Production Network, wherein economies are more open than ever before, either industrialization or deindustrialization cannot be understood in terms of the characteristics of domestic economy alone (Singh, 1977). In a similar vein, Rodrik (2005) observed that when developing countries that hitherto followed import substitution opened up for trade, their manufacturing sectors were hit by a double whammy. Industries without comparative advantage become net importers of manufacturing, reversing a long process of import substitution. In addition, they are subjected to "imported" deindustrialization from the advanced countries, because they get exposed to the relative price trends produced in the advanced economies. In sum, to quote Rodrik (2005) "while technological progress is no doubt a large part of the story behind employment deindustrialization in the advanced countries, in the developing countries trade and globalization likely to have played a comparatively bigger role".

\subsection{Deindustrialization and innovation}

Deindustrialization, however, has not been associated with any decline in the share of manufacturing in global output. The pioneers that harnessed this opportunity for their manufacturing catch up and structural transformation include Brazil and Argentina in Latin America and South Korea and Taiwan in Asia, among others. To the extent that there have been winners and losers in this process, the underlying reasoning has to be in terms of their differential capability to compete in the world market, which over time has diverged among the developing countries. There is a general con- 
sensus that the international competitiveness in the long run is governed by the innovation capabilities, which is a progeny of the innovation system of the country concerned. Hence, any inquiry into the underlying factors for deindustrialization has to begin with the learning, innovation and competitiveness building systems of the country concerned.

\subsection{India's approach towards innovation capabilities}

India is one of the developing countries at its early stage of development itself recognized the key role of science, technology, and innovation in economic transformation. The science and technology paradigm for India was laid down unambiguously by the Science Policy Resolution (SPR) passed by the Indian Parliament in 1958 which underlined the need for pursuing self-reliance in technology. To quote "in industrializing a country heavy price has to be paid in importing science technology and early and large-scale development of science and technology in the country could there for greatly reduced the drain on capital". Hence the SPR aimed to "foster, promote, and sustain, by all appropriate means, the cultivation of science and scientific research in all its aspects-pure applied and educational". Accordingly, an elaborate institutional architecture for promoting innovation has been established.

Perhaps, one of the most influential institutional intervention at the instance of the state towards building indigenous technological capability is the Patent Act of 1970. The key provisions of this Act that helped building technological capabilities include; adoption of process patents in place of product patenting for chemicals, strict compulsory licensing provisions and the role of state in pricing of patented products (Joseph and Abrol, 2009). The Act aimed at protecting the nascent domestic industry and reduced the life of patent from 14 to five years from the date of sealing of the patent or seven years from date of filing, whichever was earlier. The agenda was taken forward with the Science Policy Statement (SPS) of 1983 with its stated objective to facilitate development of indigenous technology and efficient absorption and adaptation of imported technology in sync with the national priorities and resource endowments. As Patel (1993) observed, "the maze of institutions for science and technology is an outstanding testimony to the wide spread of the scientific and technology 
infrastructure. India has no rival in the whole third world for the vastness of infrastructure and even many among the highly developed countries could not be able to rival India in the number and the spread of the institutions" ( $p$ 34). These institutions, apart from their wider contribution in the field of their specialization, became the largest source of experienced scientists/technologists for in-house R\&D activities in the country (Desai 1980, as cited in Joseph and Abrol, 2009).

While the importance of innovation capability for building international competitiveness under globalization has been reiterated, there has been greater reliance on external sources of technology. Restrictions on the access to foreign technology, both embodied and disembodied, were reduced along with a highly welcoming approach towards FDI that has been evident in the new Industrial Policy of 1991. With World Trade Organisation (WTO) the restrictions on the access to both foreign capital and technology were removed. Further, Intellectual Property Rigths (IPR) regime has also been changed to enable the owners of intellectual property to reap the highest possible returns by providing them with the monopoly power. Another notable deviation from the past has been the greater involvement of the private sector not only in policy making but also in planning and regulation along with new to encourage Indian companies to invest abroad and help facilitate greater access to technology, human capital and market owned by the foreign firms (Pradhan, 2004). It was envisaged that such measures would induce the private sector to make greater investments in R\&D.

The state's commitment to innovation was further evident when the 2010-20 decade was designated by the President of the country as a 'decade of innovation'. The Prime Minister's Office prepared a strategy paper laying down the roadmap for a 'decade of innovation', wherein innovation has been understood in a broader perspective. The roadmap departs from the earlier S\&T policies when it states: "while we do need to increase R\&D investment and efforts, this view of innovation is based on a myopic perception that restricts it to the confines of formal R\&D". Given its broader approach towards innovation and considering the diversity of the country, it also called for the establishment of innovation councils at the national, state, and sectoral levels. Science, Technology and Innovation Policy (STIP) 2013 made a point of departure from the earlier S\&T policies when it focused on "Science, technology and innovation for the 
people" and highlighted the role of innovation in fostering inclusive and sustainable development. The Roadmap, along with the STIP 2013, presented the broad contours of the new inclusive innovation paradigm and the trajectory therein. The focus of innovation was further evident from the Make in India program which envisaged making India the most favourable destination for 'Foreign Direct Investment' and developing India into a 'Global Manufacturing Hub' by facilitating investment, innovation and skill development. Further initiatives included, Digital India and Skill India. The former aimed at making available Government services to citizens electronically by better Internet connectivity and making the country digitally empowered. The latter, initiated in 2015, aimed at training over 400 million people in different skills by 2022. Yet another complementary initiative to promote innovation and entrepreneurship is the Atal Innovation Mission' (AIM), which serves as a platform for the promotion of world-class innovation hubs and self-employment activities in technology-driven areas.

\section{Data sources and period of analysis}

The study draws data from several sources. We used KLEMS (Capital, Labour, Energy, Materials and Services) India database (available from 198081 to 2015-16) published by the Reserve Bank of India (RBI) for sectoral shares. We have used UNCTAD (available from 1970 to 2015) database for computing India's share in world manufacturing. The export unit value index is computed using COMTRADE data. The data on R\&D and patents is obtained from UNESCO database and Department of Science and Technology, India. Given the focus of present paper on manufacturing, data on value added, output, fixed capital, profits and data on other important variables are obtained from Annual Survey of Industries (ASI) at the 2-digit level of National Industry Classification 2004-04. The data for the latest year (2017-18) is obtained from the Annual Survey of Industries (ASI) published by the Central Statistical Organization (CSO), India. Similarly, we have obtained the data on contract workers and wages from published records of ASI. Using the concordance tables provided by CSO, we have concorded the data in 2004-05 NIC. The latest year for the ASI data is 2017-18. Therefore, the period of analysis of the study is from 1980-81 
to 2017-18. However, the detailed data on contract labour is available only from 1993 onwards. We have constructed industry-wise Wholesale Price Index (WPI) in 2004-05 constant prices using the data provided by the economic advisor, industry to deflate the nominal values. Similarly, we have used the Consumer Price Index for Industrial Workers (CPI-IW) to deflate the wages and salaries.

The period of the empirical analysis varies depending on data availability. We have maintained consistency in period of analysis covering both pre-globalization (from 1980 to 1995) and post-globalization (1995 onwards) to the extent possible. Data for some indicators like contract workers representing quality of employment and $R \& D$ intensity representing innovation capabilities is not available prior to 1995. In the absence of comparable data, we supplemented pre-globalization trends with secondary literature.

\section{Deindustrialization and catch up: India's experience}

India, from its early days of planning, has been persistent with industrialization as its catch-up strategy towards transforming the backward agrarian economy that was inherited from the colonial rulers. Needless to say, this was inspired by Kaldor's ideas on the potential of the industry sector to help economic growth and catch up of developing countries. India's efforts overtime through various institutional interventions on building a manufacturing base has given rich dividends. The focus of these initiatives in the earlier period was to build an import-substituting, regionally balanced and diversified industrial base at the instance of public sector and increased role for small-scale sector under the umbrella of protection and regulation.

In sync with the shift in policy pendulum across the developing world from planning under import substitution to export orientation and globalization, India's strategy also shifted towards market-oriented global integration. This implied inter alia the dismantling of industrial licensing along with getting rid of all the man-made barriers to FDI, the removal of reservations for the micro, small and medium enterprises (MSMEs). Though the changes in the policy framework could be traced to the early 1980s, with India's joining in WTO as one of the founding members, the process of globalization accelerated momentum. These initiatives, as already 
documented by different scholars, have paid rich dividends, as manifested by a marked increase in the inflow of industrial investment, both local and foreign, high growth in the manufacturing output along with its bearing on the structural change in the economy with its implications on manufacturing driven catch up - the focus of the current inquiry.

Following the early literature on deindustrialization, we shall begin with an analysis of the manufacturing employment share. We divide the period of analysis into two phases: pre-globalization period (1980-95) and globalization period (1995-2016) after India joining the WTO. During the pre-globalization period, the share of manufacturing employment remained constant around 10 percent with hardly any change. However, in the post globalization, it has marginally increased from 10.4 percent to 11.8 percent (Figure 1). This trend is further reinforced as the employment growth increased from 1.7 percent during pre-globalization phase to 2.6 percent after globalization period. Our finding is in line with Dasgupta and Singh (2005) who argued that while India's manufacturing employment has not been expanding in the formal sector, employment in informal sector been growing. Thus, there is no clear evidence of deindustrialization going by the share in manufacturing employment.

\section{Figure 1 Trend in the sectoral distribution of employment in India}

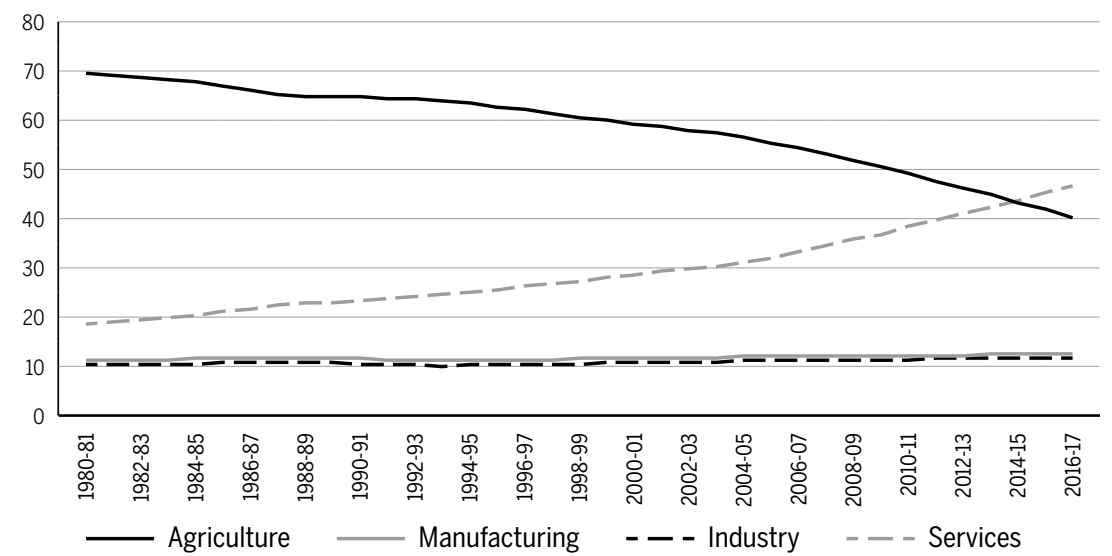

Source: Authors' calculation based on KLEMS, India 2019, RBI.

Following Tregenna (2009), we have also analysed the trends in contribution of manufacturing sector to GDP. Figure 2 indicates a marginal increase 
in the share of manufacturing GDP (from 18.7 percent to 20.7 percent) during the pre-globalization period. In the post globalization period, the contribution of manufacturing to total GDP showed a clear decline starting from 2006-07 to 2016-17. During this period, it declined from 19.7 percent to 16.82 percent. This declining trend in the share of manufacturing GDP when the per capita income has not even crossed US $\$ 2000$ could be considered as an evidence of deindustrialization.

\section{Figure 2 Trend in the share of different components of GDP in India}

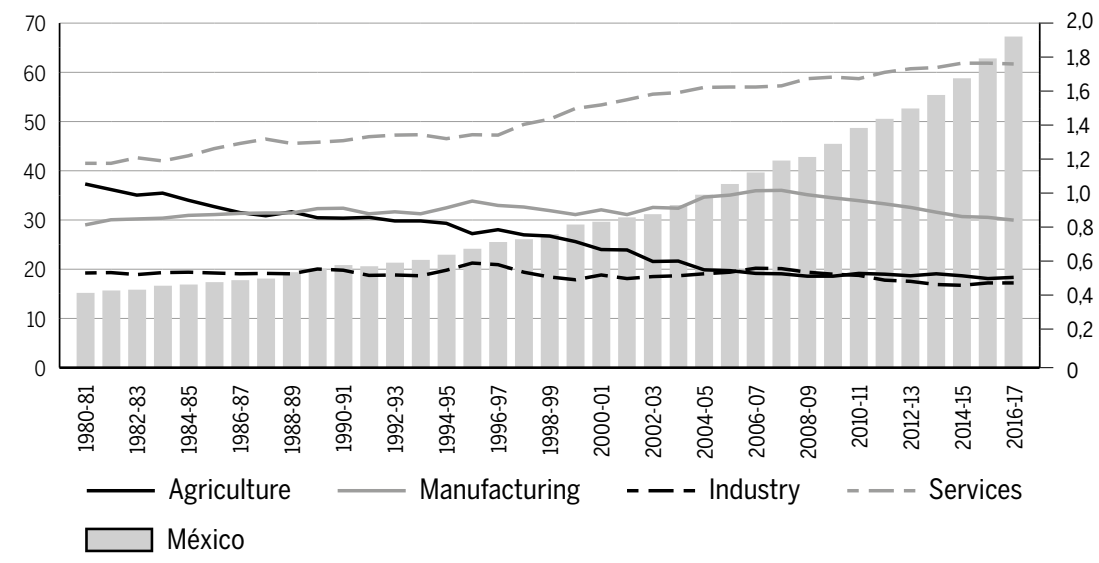

Source: Authors calculation based on KLEMS, India 2019, RBI.

Note: Per-capita income is 2010 USD constant prices.

The observed decline in the share of manufacturing sector, while the per capita income of India is still far below the postulated peak for turnaround in manufacturing GDP, attracted the attention of scholars (Kumar 2017; Amirapu and Subramanian 2015; Chaudhuri, 2015). Some of these studies have concluded that the manufacturing sector in India has been undergoing a phase of premature deindustrialization. Analysing import dependency of final consumption in India by making use of Input-Output Tables for 2001-2011 period Kumar (2017) argued that the rising share of imports in final consumption or import dependence would tend to indicate deindustrialization taking place in India. In a similar vein, Amirapu and Subramanian (2015), after analysing the state level data on manufacturing value added, argued that to call the Indian phenomenon deindustrialization is to dignify the Indian experience, which could more aptly be referred to 
as premature non-industrialization because India never industrialized sufficiently in the first place.

While the existing studies confirm deindustrialization in India, our analysis using manufacturing value added and employment lead us to a riddle: manufacturing employment share increased and value-added share declined. This riddle could be seen as an outcome of the competitive strategies adopted by firms under globalization. As we already argued, given the widely prevalent wage-cutting strategy of firms to be internationally competitive and increasing appeal for flexibility in labour market, the employment generated may be of low quality and thus weaken the Keynesian multiplier effect of industrialization. Therefore, to analyse this issue, one needs to go beyond the total employment and reflect on the quality of employment generated.

\subsection{Quality of employment}

It has been argued that in many countries the heterogeneity of employment types has increased over the last decades with non-standard types of employment substantially grown while the share of standard full-time jobs with open-ended contract has decreased. As a result, there is a growing concern among the policy makers and the multilateral organizations like the International Labour Organization (ILO) on the quality of employment being generated. In the case of ILO, along with quantity of employment, the focus has been increasingly on worker rights; employment creation; social protection; and social dialogue between workers' organizations, employers' organizations, and calls for promoting opportunities for men and women to obtain decent and productive work (Joseph and Kakarlapudi, 2019). At this juncture, it is important to note that Europe 2020 strategy highlighted employment and job quality as the core elements for smart, sustainable and inclusive growth. United Nations Economic Commission for Europe (2015) has suggested different indicators of the quality of employment, which include (1) safety and ethics of employment, (2) income and benefits from employment, (3) working time and work-life balance, (4) security of employment and social protection, (5) social dialogue (6) skills development and training and (7) employmentrelated relationships and work motivation work (Joseph and Kakarlapudi, 
2019). Since the focus in the Indian context is apparently on the quantity of employment, the quality considerations are yet to receive much attention of policymakers and we have very limited database on the above indicators. For the present purpose, we have gathered information on the number of contract workers.

Earlier studies have observed that much of the employment growth under liberalization has been on account of the growth in contract employment (Uma et al. 2010). During 1996-2003, growth in the employment of direct workers was found to be negative ( -1.96 percent) whereas the contract employment registered a growth rate of 8.15 percent. High growth of contract workers continued and increased at a rate of 8.14 percent during 2004-15 while the direct employment growth was only at 3 percent (Joseph and Kakarlapudi, 2019). While those employed on contract basis are paid poorly and not entitled to any social security benefits unlike those employed directly, the quality of employment of the contract work is presumed to be low. Figure 3 presents share of contract workers in total employment. It is evident that high growth of contract employment is manifested in increasing share of contractual workers in total employment that recorded an almost three-fold increase from 10 percent in 1993 to 28.7 in 2017.

\section{Figure 3 Trend in the share of contract labor in India's organised manufacturing sector}

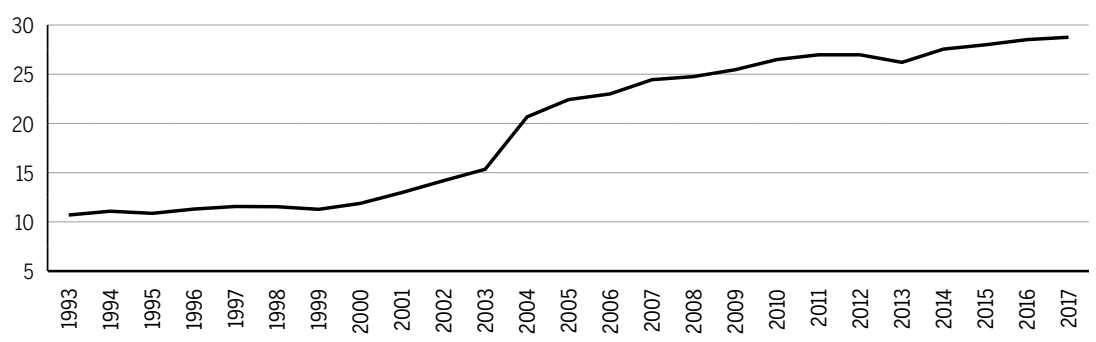

Source: Authors calculation based on ASI data, various years.

Incidentally, the change in the pattern of employment with respect to quality of employment generated is bound to have its implications on the extent of value addition from manufacturing on the one hand and its distribution between wages and profits on the other. It is evident from Figure 4 that the value addition capability of India's manufacturing sec- 
tor has shown a marginal increase during the pre-globalization period but declined under globalization. To illustrate, figure 4 shows that the value added as a proportion of output showed an upward trend to reach $23 \%$ in 1995-96. But since then, there been a steady decline to reach the lowest share - 15\% - in 2011, although an upward trend is visible after 2011 the observed share during the terminal year is only $18 \%$, that is much lower than what was recorded in 1995. But what is relevant for the present discussion is the bearing of the quality of employment on the value addition capacity of the manufacturing sector.

\section{Figure 4 Trend in the share of value added in India's manufacturing output}

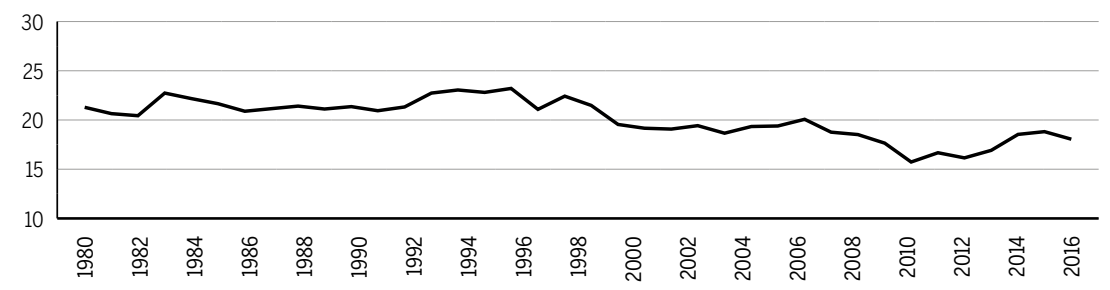

Source: Authors calculation based on ASI data, various years.

As already indicated, the declining quality of employment is bound to have its implications on the distribution of the value addition generated between wages and profits, which in turn is bound to have its implications on inequality as well. Figure 5 presents the share of wages and profits in value added. In sync with the observed increase in the incidence of contract workers, the share of labour in value added declined from 28.6 per cent in 1980-81 to 9 percent in 2007. Though there has been an upward trend thereafter, the share in 2016 is not even $50 \%$ of what prevailed in 1980. This seems to suggest that the growing share of manufacturing employment in India was not necessarily helpful for development by promoting opportunities for men and women to obtain decent and productive work. Further, it is unlikely that the growing manufacturing generated the Keynesian type demand growth impulse expected from a growing manufacturing sector.

Along with this trend, the share of profit in value added in the organized manufacturing sector recorded a remarkable increase from 18.5 per cent in 1991 to 54 per cent in 2007-08. A decline in the share of profit thereafter, 
notwithstanding the share of profit in 2016 , is over $40 \%$, indicating its implications for the growing inequality. The declining share of wages and increase in the share of profit also tends to suggest a process of immiserising competitiveness building process in a period of heightened competition under globalization. The declining share of wages, as is evident from Figure 6 , has been associated with an increasing trend in labour productivity and declining labour intensity in production. True, there has been an increase in real wage rate. But what is important to note, is that the growth in real wage rate lagged much behind the growth in labour productivity.

Figure 5 Trend in the share of wages and profit in the value added in India's organized

\section{manufacturing sector}

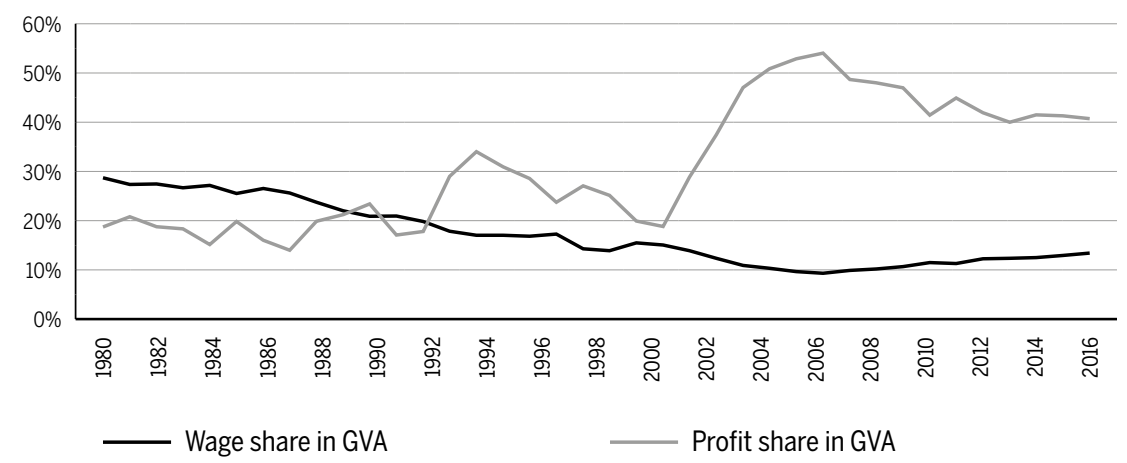

Source: Authors calculation based on ASI data, various years.

Figure 6 Trends in labour productivity and real wages

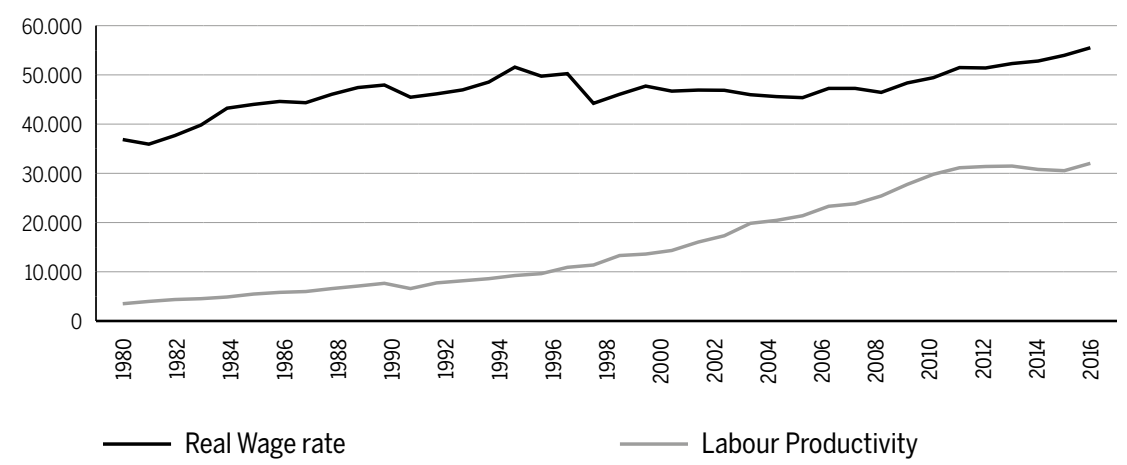

Source: Authors calculation based on ASI data, various years. 
Table 1 Real wage growth and labour productivity growth in India's manufacturing industries

\begin{tabular}{|c|c|c|c|c|c|c|}
\hline \multirow[t]{2}{*}{ NIC } & \multicolumn{3}{|c|}{ Phase 1 (1980-95) } & \multicolumn{3}{|c|}{ Phase 2 (1996-2017) } \\
\hline & $\begin{array}{l}\text { Wage } \\
\text { share }\end{array}$ & $\begin{array}{r}\text { Wage } \\
\text { growth }\end{array}$ & $\begin{array}{r}\text { Labour } \\
\text { productiv- } \\
\text { ity growth }\end{array}$ & $\begin{array}{l}\text { Wage } \\
\text { share }\end{array}$ & $\begin{array}{l}\text { Wage } \\
\text { growth }\end{array}$ & $\begin{array}{l}\text { Labour } \\
\text { productiv- } \\
\text { ity growth }\end{array}$ \\
\hline Food & 21.25 & 5.76 & 8.62 & 14.67 & 1.72 & 5.78 \\
\hline Tobacco & 33.96 & 1.96 & 1.32 & 14.97 & 0.68 & 4.28 \\
\hline Textile & 41.63 & 0.78 & 6.62 & 24.83 & -0.20 & 6.32 \\
\hline Garment & 22.13 & 1.58 & 4.51 & 27.82 & 2.12 & 1.94 \\
\hline Leather & 28.51 & 0.03 & 5.57 & 25.84 & 1.22 & 2.43 \\
\hline Wood & 27.21 & 1.88 & 1.64 & 20.26 & 2.83 & 7.11 \\
\hline Paper & 22.68 & 1.96 & 4.20 & 17.21 & 0.20 & 4.92 \\
\hline Printing & 32.60 & 3.16 & 8.01 & 14.03 & 0.10 & 5.61 \\
\hline Petroleum & 7.97 & 4.47 & 4.72 & 3.77 & 1.57 & 9.73 \\
\hline Chemical & 13.82 & 2.00 & 6.77 & 7.38 & 0.33 & 4.35 \\
\hline Rubber & 17.24 & 1.66 & 6.32 & 13.02 & 0.85 & 5.28 \\
\hline $\begin{array}{l}\text { Non- } \\
\text {-Metallic }\end{array}$ & 20.69 & 2.19 & 6.88 & 12.21 & 0.59 & 5.01 \\
\hline Metals & 22.99 & 2.90 & 5.44 & 12.20 & 0.52 & 6.77 \\
\hline Metal Pro & 20.41 & 2.44 & 6.40 & 17.30 & 1.54 & 5.75 \\
\hline Machinery & 23.95 & 2.89 & 6.86 & 13.80 & -0.10 & 7.39 \\
\hline Computing & 13.35 & 1.06 & 14.01 & 6.10 & 2.09 & 8.68 \\
\hline $\begin{array}{l}\text { Electrical } \\
\text { Machinery }\end{array}$ & 19.97 & 2.30 & 5.10 & 13.48 & -0.76 & 5.08 \\
\hline Radio, TV & 19.62 & 1.54 & 8.88 & 10.58 & 1.02 & 11.25 \\
\hline $\begin{array}{l}\text { Medical } \\
\text { instruments }\end{array}$ & 17.61 & 3.18 & 6.94 & 12.74 & 0.94 & 12.01 \\
\hline $\begin{array}{l}\text { Motor } \\
\text { vehicle }\end{array}$ & 22.69 & 3.66 & 9.44 & 14.21 & -1.20 & 5.28 \\
\hline Transport & 43.39 & 2.01 & 7.75 & 15.95 & 0.56 & 10.60 \\
\hline Furniture & 26.92 & 2.92 & 8.26 & 19.03 & 0.36 & 11.24 \\
\hline Total & 23.41 & 2.32 & 6.88 & 12.58 & 0.40 & 5.92 \\
\hline
\end{tabular}

Source: Authors calculation based on ASI data, various years.

Going beyond the aggregate analysis, we analyse below the industry-wise trends in wage share, wage growth and productivity growth to understand the main drivers of the trends observed in the aggregate analysis. 
From Table 1 it is evident that average wage share declined in most of the industries during the globalization period, except in the garment industry, where the wage share increased from 22.13 percent in the first phase to 27.82 in the globalization phase. The decline in wage share during the globalization period is the highest in transport industry (27.44 per cent), followed by tobacco (19), printing (18.5) and textiles (16.8). For the manufacturing sector as a whole, wage share in the globalization period halved from 23.45 to 12.8 . The decline in wage share could be attributed to decline in productivity growth or decline in real wages. As evident from the table, growth in real wage rate lagged much behind the productivity growth in all the industries during both periods. What is more important to note is that the extent of difference between growth in real wages and productivity growth increased significantly during the globalization period. The growing wedge between growth in real wage and productivity growth has to be seen in terms of the declining quality of employment as manifested in the increasing incidence of contract labour.

\section{Deindustrialization and innovation}

From the discussion thus far, it is evident that, like many other developing countries, India has also been experiencing deindustrialization under globalization. Globalization has led to the establishment of Global Production Network (GPN) at the instance of Multi National Corporations (MNCs) facilitated by trade and investment liberalization. Therefore, the potential for enhancing the industrial performance of developing countries by raising their share manufacturing output and employment depends on their ability to participate in such GPNs. To the extent that the establishment of GPNs is part of the competitive strategy of MNCs to survive under heightened international competition, the participation of developing countries in GPN is contingent on their potential for being the source of certain specialized capabilities that the MNCs need in order to complement their own core competence (Ernst and Lundvall 2000; Kaplinski 2000). In the modern world the most sought-after such capability is the innovation capability. There is no guarantee that the returns of such global integration would be positive and equally distributed (Kaplinski 2000). The dividends depend on the positioning of developing countries in the GPNs and their capabil- 
ity to get rid of the risk of being locked up in the lower end of the value chain (Durán 2019). This in turn is invariably governed by the innovation capability of the country concerned. Hence, there is reason to argue that any inquiry into the deindustrialization under globalization has to begin with the innovation capability. The innovation system perspective, which is the most popular approach in innovation studies (Fagerberg and Sapprasert 2011), considers innovation capability as the progeny of the innovation system, at the national regional and sectoral level, of the country concerned. Though an analysis of the innovation system could help to highlight the underlying factors of deindustrialization, such an inquiry is beyond the scope of the present study. Hence, we shall focus on the oftenused indicators of innovation capability such as research and development.

The declared commitment towards building innovation capability under globalization notwithstanding, the empirical evidence tends to suggest that the performance with respect to $\mathrm{R} \& \mathrm{D}$, the crucial indicator of innovation, has not been remarkable. It is evident from Figure 7 that while the R\&D intensity showed an upward trend for about 12 years since 1996 to reach a level of $0.9 \%$ in 2008 , there has been a downward trend thereafter, such that the R\&D intensity at present is only at the level of $1996(0.65 \%)$. Here one could mention an R\&D intensity of about $2.1 \%$ for China, a target that India has been upholding for many years. The lacklustre performance with respect to $R \& D$ under globalization has to be compared with the fact that during the 1970s the annual average growth rate in $\mathrm{R}$ \& D expenditure $(8.34 \%$ ) was at a higher rate than the corresponding increase in the direct cost of technology import $(7.7 \%)$ during the seventies (Subrahmanian 1991).

\section{Figure 7 Trend in R\&D intensity (R\&D as \% of GDP) in India}

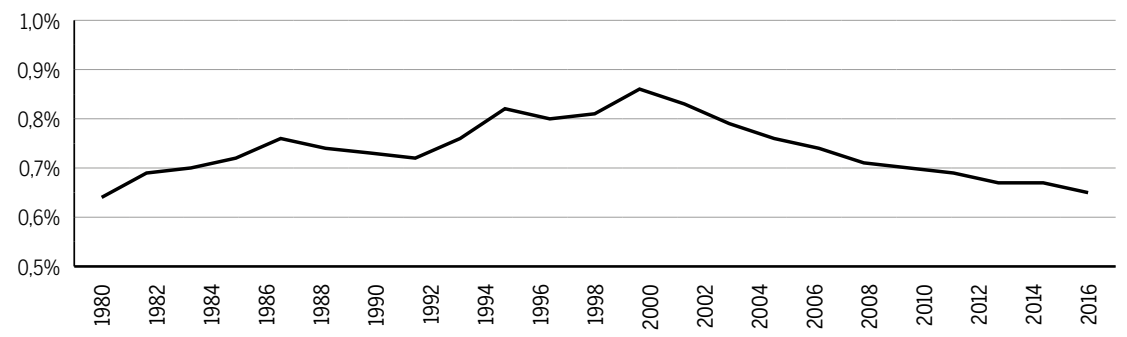

Source: Based on UNESCO database. 
Based on an analysis of R\&D intensity in India vis-à-vis 10 other countries (both developed and developing), Joseph and Abrol (2009) observed that during 1973-82 R\&D intensity (R\& D Expenditure as a proportion of GNP) in India increased by 0.4 percent. Among the countries compared, only Brazil presented a better performance than India and only the Federal Republic of Germany kept pace with India. However, 16 years after 1982, the recorded increase in India was negligible $(0.01 \%)$ and that of most other countries in the sample recorded a much better performance than India.

Table 2 Share of high tech and low-tech industries in output, employment, GVA and wage share in India's manufacturing sector

\begin{tabular}{l|r|r|r|r}
\hline \multirow{2}{*}{ Year } & Low-tech industries & \multicolumn{2}{|r}{ High-tech industries } \\
\cline { 2 - 5 } & $\begin{array}{r}\text { Output share in } \\
\text { manufacturing }\end{array}$ & $\begin{array}{r}\text { Employment share } \\
\text { in manufacturing }\end{array}$ & $\begin{array}{r}\text { Output share in } \\
\text { manufacturing }\end{array}$ & $\begin{array}{r}\text { Employment share } \\
\text { manufacturing }\end{array}$ \\
\hline 1980 & 67.4 & 74.1 & 32.6 & 25.9 \\
\hline 1983 & 68.2 & 73.4 & 31.8 & 26.6 \\
\hline 1986 & 67.5 & 72.1 & 32.5 & 27.9 \\
\hline 1989 & 66.2 & 71.8 & 33.8 & 28.2 \\
\hline 1992 & 64.8 & 71.0 & 35.2 & 29.0 \\
\hline 1995 & 63.1 & 70.0 & 36.9 & 30.0 \\
\hline 1998 & 63.1 & 68.5 & 36.9 & 31.5 \\
\hline 2001 & 65.0 & 73.5 & 35.0 & 26.5 \\
\hline 2004 & 65.4 & 73.4 & 34.6 & 26.6 \\
\hline 2007 & 68.5 & 73.1 & 31.5 & 26.9 \\
\hline 2010 & 67.4 & 70.9 & 32.6 & 29.1 \\
\hline 2013 & 69.7 & 70.2 & 30.3 & 29.8 \\
\hline 2016 & 65.7 & 69.3 & 34.3 & 30.7 \\
\hline 2017 & 65.3 & 68.7 & 34.7 & 31.3 \\
\hline 5
\end{tabular}

Source: ASI, various years.

Given the poor performance with respect to innovation, the share of hightech industries in manufacturing output and employment, while showing an upward trend during pre-liberalization, has been on a declining trend under globalization (table 2). The declining trend is also evident with respect to the share of value added in output and share of wages in value added.

At the same time, select sectors like software and IT enabled services attracted worldwide attention under globalization. (Kumar 2001, Arora 
et.al 2001, Joseph 2002, Kumar and Joseph 2005 to list a few). However, it was also shown that the excessive export orientation has had adverse effect on the innovation activity in the industry (Parthasarathi and Joseph 2002). Further, the remarkable growth of the IT sector has had it adverse effect on other sectors competing for skilled manpower, like manufacturing, through the resource movement effect (Joseph and Harilal 2001). In the case of Electronics sector, while the products having higher linkages in terms of imports recorded remarkable growth, those products with higher linkages with respect to value added and employment lagged behind in output growth (Joseph 1997). On the whole, while the commitment towards building technological capability has been reiterated under globalization, investment in R\&D for technology capability building has not even kept pace with the GDP growth.

Table 3 Growth in quantum index and unit value index of India's exports 2010-11 to 2017-18

\begin{tabular}{|c|c|c|}
\hline Commodity & $\begin{array}{l}\text { Trend growth in } \\
\text { quantum index }\end{array}$ & $\begin{array}{l}\text { Trend growth in } \\
\text { unit value index }\end{array}$ \\
\hline Electrical Machinery & 5.3 & 2.4 \\
\hline Gen Purpose Machinery & 15.4 & 0.19 \\
\hline Iron and steel & 7.25 & 1.5 \\
\hline Leather & -1.35 & 10 \\
\hline Metal working machinery & 8.8 & 2.6 \\
\hline Office machines & -2.9 & 9.1 \\
\hline Other transport equipment & 8.2 & -0.15 \\
\hline Pearls & -6.3 & 10.8 \\
\hline Power generating machinery & 18.4 & -2.09 \\
\hline Road Vehicles & 4.7 & 10.96 \\
\hline Special Purpose machinery & 6.6 & 6.1 \\
\hline Tele communication equipment & -12.3 & 4.9 \\
\hline Textile & 4.4 & 5.37 \\
\hline
\end{tabular}

Source: Authors' calculation based on UNCOMTRADE database.

In this context, an analysis of the performance of different commodity groups with respect to unit value index and the quantum index is of much relevance. An analysis the growth of unit value index and the quantum index for 13 major commodity groups has shown that the growth of unit 
value index in 9 commodities is lower than the quantum index (see table 3). The lower growth in the unit value index cannot be delinked from the declining wage rate and wage share that we have articulated as an integral part of India's deindustrialization process. Thus viewed, the deindustrialization in India may be seen as an outcome of its strategy to build international competitiveness under globalization based on price/wage cost advantage in place of innovation-based comparative advantage.

\section{Conclusions}

While many of the developing countries under import substitution managed to develop a manufacturing base, which is considered as an engine of growth, evidence tends to suggest that under globalization manufacturingdriven catch up is no longer an opportunity for the developing countries. Analysing the long-term trends in the share of manufacturing employment and output across countries, scholars have raised concerns about premature deindustrialization taking place in the developing countries, at a much lower level of per capita income and at a far lower level of industrialization as compared to developed countries. Deindustrialization without industrialization has also been observed by scholars in the case of countries in Sub Saharan Africa, where the share manufacturing employment and value added have been showing declining trends even before they embark upon industrialization and with per capita income not even crossing \$ 1000 .

This study examined deindustrialization in India under globalisation and highlighted an apparent riddle. Although there has been no conclusive evidence of deindustrialization as per the trend in the share of manufacturing employment, there is compelling evidence in this direction with respect to the share of manufacturing output in GDP. However, increase in the share of manufacturing employment has been accompanied by a decline in the quality of employment, evidenced by a three-fold increase in contract employment resulting in a declining growth in real wages and a corresponding decline in the share of wages in value added. To the extent that wages and not necessarily employment matter in the generation of Keynesian type demand growth impulse, our analysis based on the Indian experience underlined the need to go beyond manufacturing employment and output while analysing deindustrialization. Further, since develop- 
ment could be construed as a process that enables men and women to obtain decent and productive work, trends in employment share alone could conceal more than what they reveal.

Exploring the roots of deindustrialization in India under globalization, it has been shown that the declared commitment towards building innovation capability notwithstanding, $R \& D$ investment, the crucial indicator of innovation, has not even kept pace with GDP growth. As a result, $\mathrm{R} \& \mathrm{D}$ intensity under globalization showed a marked decline and it is at a much lower level $(0.6 \%)$ when compared to countries like China $(2.1 \%)$ or South Korea. There has also been a decline in the share of high technology products in India's manufacturing sector and lower growth in the unit value index of exports. Based on these findings, the study argues that the deindustrialization in India may be seen as an outcome of the strategy under globalisation to build international competitiveness based on price/ wage cost advantage and the failure to build a vibrant learning, innovation and competence building system as has happened in the case of the successful catch-up episodes.

\section{References}

ALBUQUERQUE, E. M. Brazil and the Middle-Income Trap: Its Historical Roots. Seoul Journal of Economics, v.32, i.1, 2019.

ALDERSON, A. S. Explaining deindustrialization: globalization, failure, or success? American Sociological Review, v.64, i.5, pp. 701-721, 1999.

AMIRAPU, A.; SUBRAMANIAN, A. Manufacturing or services? An Indian illustration of a development dilemma. Center for Global Development Working Paper, (408), 2015.

ARORA. A.; ARUNACHALAM, V. S.; ASUNDI, J.; RONALD, F. The Indian software services industry. Research Policy, v.30, i.3, pp. 1267-1287, 2001.

ATKINSON, A. B.; PIKETTY, T.; SAEZ, E. Top incomes in the long run of history. Journal of economic literature, v.49, i.1, pp. 3-71, 2011.

ATOLIA, M.; LOUNGANI, M. P.; MARQUIS, M.; PAPAGEORGIOU, M. C. Rethinking Development Policy: Deindustrialization, Servicification and Structural Transformation. International Monetary Fund, 2018.

CHAUDHURI, S. Import liberalisation and premature deindustrialisation in India. Economic and Political Weekly, v.50, i.43, pp. 60-69, 2015.

DASGUPTA, S.; A. SINGH. Will services be the new engine of Indian economic growth? Development and Change, v.36, i.6, pp. 1035-1057, 2005.

DESAI, ASHOK, V. The origin and direction of industrial R\&D in India. Research Policy, v.9, 
i.1, pp. 74-96, 1980.

DURÁN, C. R. Globalization and the Scrambling Process of Catching Up in Mexico. Seoul Journal of Economics, v.32, i.1, 2019.

DURLAUF, S. N. The rise and fall of cross-country growth regressions. History of Political Economy, 41(Suppl_1), pp. 315-333, 2009.

FAGERBERG, J.; SAPPRASERT, K. National innovation systems: the emergence of a new approach. Science and public policy, v.38, i.9, pp. 669-679, 2011.

FEI, J.C.H.; RANIS, G. Development of the Labour Surplus Economy: Theory and Policy. Irwin, Homewood, IL, 1964.

FELIPE, J.; MEHTA, A. Deindustrialization? A global perspective. Economics Letters, 149, pp. 148-151, 2016.

INTARAKUMNERD, P. Thailand's Middle-Income Trap: Firms' Technological Upgrading and Innovation and Government Policies. Seoul Journal of Economics, v.32, i.1, 2019.

JOSEPH, K. J.; ABROL, D. Science, technology and innovation policies in India: Achievements and limits. BRICS and development alternatives: Innovation systems and policies, 1, 101, 2009.

JOSEPH, K. J.; KAKARLAPUDI, K. K. Export-Employment Conundrum in India's Manufacturing Under Globalization: In Search of a Strategic Approach. pp. 111-152. In: Manufacturing and Jobs in South Asia. Springer, Singapore, 2019.

JOSEPH, K. J. Growth of ICT and ICT for Development: Realities of the Myths of Indian Experience, Discussion paper No. 2002/78, Helsinki: UNU/ WIDER, 2002.

JOSEPH, K. J. Industry under Economic Liberalization: The case of Indian electronics, Sage publications, New Delhi, Thousand Oaks, London. 1997.

JOSEPH, K.J.; HARILAL, K. N.; Structure and growth of India's IT exports: Implications of an export-oriented growth strategy. Economic and Political Weekly, v. 36, i.34, pp. 3263-3270, 2001.

KALDOR, N. Essays on economic stability and growth. No. HB171 K28, 1960.

KALDOR, N.; Causes of the Slow Rate of Growth of the United Kingdom. Cambridge University Press, Cambridge, 1966.

KAPLINSKI, R. Globalisation and unequalisation: What can be learned from value chain analysis? The Journal of Development Studies, v.37, i.2, pp. 117-146, 2000.

KUMAR, N. Reversing pre-mature deindustrialization for jobs creation: lessons for 'Make-in-India' from experiences of industrialized and East Asian countries. No. 208. RIS discussion paper. 2017.

KUMAR, N. Indian Software Industry Development: International and National Perspective. Economic and Political Weekly, v.36, i.45, pp. 4278-4290, 2001.

KUMAR, N.; JOSEPH, K.J. Export of Software and Business Process Outsourcing from Developing Countries: Lessons from India. Asia Pacific Trade and Investment Review, v. 1, i.1, pp. 91-108, 2005.

PALMA, J. G. Homogeneous middles vs. heterogeneous tails, and the end of the 'inverted-U': It's all about the share of the rich. Development and Change, v. 42, i.1, pp. 87-153, 2001. 
PALMA, J. G. De-industrialisation, 'premature' de-industrialisation and the dutch-disease. Revista NECAT-Revista do Núcleo de Estudos de Economia Catarinense, v.3, i.5, pp 7-23, 2014.

PALMA, J.G. Deindustrialisation, premature deindustrialisation, and the Dutch disease. In: BLUME, L.E.; DURLAUF, S.N. (eds.). The New Palgrave: A Dictionary of Economics, $2^{\text {nd }}$ edition, Basingstoke: Palgrave Macmillan, pp. 401-410, 2008.

PARTHASARATHI, A.; JOSEPH, K.J. Limits to innovation with strong export orientation: The case of Indian information communication technology sector. Science Technology and Society, v.7, i.1, 2002.

PATEL, S. Technological self-reliance in India, Ashish publications, New Delhi, 1993.

PIKETTY, T. Capital in the $21^{\text {st }}$ century. Cambridge: Harvard University Press, 2014.

PRADHAN, J. P. The determinants of outward foreign direct investment: a firm-level analysis of Indian manufacturing. Oxford Development Studies, v.32, i.4, pp. 619-639, 2004.

RODRIK, D. Premature deindustrialization. Journal of economic growth, v.21, i.1, pp. 1-33, 2016.

RODRIK, D. Growth after the Crisis. Harvard Kennedy School, Cambridge, MA, 2009.

ROWTHORN, R.; COUTTS, K. De-industrialisation and the balance of payments in advanced economies. Cambridge Journal of Economics, v.28, i.5, pp. 767-790, 2004.

ROWTHORN, R.; RAMASWAMY, R. Growth, trade, and deindustrialization. IMF Staff Working Papers, 1999.

ROWTHORN, R.; WELLS, J. De-industrialization and Foreign Trade. Cambridge: Cambridge University Press, 1987.

SAEGER, S.S. Globalization and deindustrialization: myth and reality in the OECD. Weltwirtschaftliches Archiv, v.133, i.4, pp. 579-608, 1997.

SEN, A. Development: Which way now? The economic journal, v.93, i.372, pp. 745-762, 1983.

SINGH, A. UK industry and the world economy: A case of de-industrialization? In: Welfare aspects of industrial markets (pp. 183-214). Springer, Boston, MA, 1977.

SUBRAMANIAN, K. K. Technological Capability under Economic Liberalism: Experience of Indian Industry in Eighties. Economic and Political Weekly, August 31, M87-89, 1991.

SZIRMAI, A. Industrialisation as an engine of growth in developing countries, 1950-2005. Structural change and economic dynamics, v.23, i.4, pp. 406-420, 2012.

SZIRMAI, A.; VERSPAGEN, B. Manufacturing and economic growth in developing countries, 1950-2005. Structural change and economic dynamics, v.34, pp. 46-59, 2015.

TIMMER, M. P.; DIETZENBACHER, E.; LOS, B.; STEHRER, R.; DE VRIES, G. J. An Illustrated User Guide to the World Input-Output Database: the Case of Global Automotive Production. Review of International Economics, v.23, pp. 575-605, 2015.

TREGENNA, F. Characterising deindustrialisation: an analysis of changes in manufacturing employment and output internationally. Cambridge Journal of Economics, v.33, i.3, pp. 433466, 2009.

TREGENNA, F. Deindustrialisation, structural change and sustainable economic growth. UNU-MERIT, 2015.

UMA, S.; JOSEPH, K. J.; ABRAHAM, V. Impact of trade liberalization on employment: The 
experience of India's manufacturing industries. Indian Journal of Labour Economics, v.16, i.4, pp. 792-814, 2010.

YASAR, M. M. Can Turkey Escape from the Middle-Income Trap? What Has Been Done? What Can Be Done? Lessons from South Korea. Seoul Journal of Economics, v.32, i.1, 2019.

\author{
About the authors \\ KJJoseph-director@gift.res.in \\ Gulati Institute of Finance and Taxation, Thiruvananthapuram, Kerala, India. \\ ORCID: https://orcid.org/0000-0003-0369-2674. \\ Kiran Kumar Kakarlapudi-kiran@gift.res.in \\ Gulati Institute of Finance and Taxation, Thiruvananthapuram, Kerala, India. \\ ORCID: https://orcid.org/0000-0002-1774-954X. \\ Akhil Joseph-akhilj780@gmail.com \\ Wealthmaker Financial Services, Sydney, Australia. \\ ORCID: https://orcid.org/0000-0002-8049-4041.
}

\title{
About the article
}

Submission received on July 07, 2020. Approved for publication on February 16, 2021. 